\title{
Retirement plan options for pensionless physicians
}

\author{
— Cite as: CMAJ 2019 September 9;191:E1014-5. doi: 10.1503/cmaj.1095795
}

Posted on cmajnews.com on August 21, 2019

$\mathbf{R}$ etirement planning has been front of mind for many Canadian physicians in recent months. More than 9000 have signed a petition asking the Canadian Medical Association (CMA) to use some of the $\$ 2.6$ billion it earned from the sale of MD Financial Management last year to create a pension plan for its members.

Because there is no employment relationship between the CMA and its members, current tax law prevents the association from contributing to a pension plan. But there are other ways the CMA, or another group, could help establish a retirement plan to provide doctors with greater long-term financial security.

Doctors registered as professional corporations can set up their own pension funds, and they can band together to set up a group multi-employer fund, which could be arranged and overseen by an organization like the CMA, said Mark Newton, founder of Newton HR Law, who helped oversee such a fund for the Canadian Bar Association.

"There's no reason why that sort of plan shouldn't work for doctors," he said.

To get started, the CMA or another organization would need to create a committee responsible for designing the plan and choosing financial providers and investment managers. "It's a lot of work up front," said Newton, but it would require minimal administration once up and running.

The first big decision would be whether to create a defined benefit plan, which guarantees a certain level of retirement income based on average final earnings, or a defined contribution plan, which is more vulnerable to the vagaries of the market.

Defined benefit plans are common in the public service, such as the Ontario Teachers' Pension Plan or the Healthcare of Ontario Pension Plan, because the government is able to cover the risk of market variability with public money, said Malcolm Hamilton, a pension expert at the C.D. Howe Institute. The government is unlikely to offer the same deal to doctors, he said.

Among private employers, defined benefit plans have fallen out of favour, after the costs of unfunded plans nearly sank the automobile industry. Only

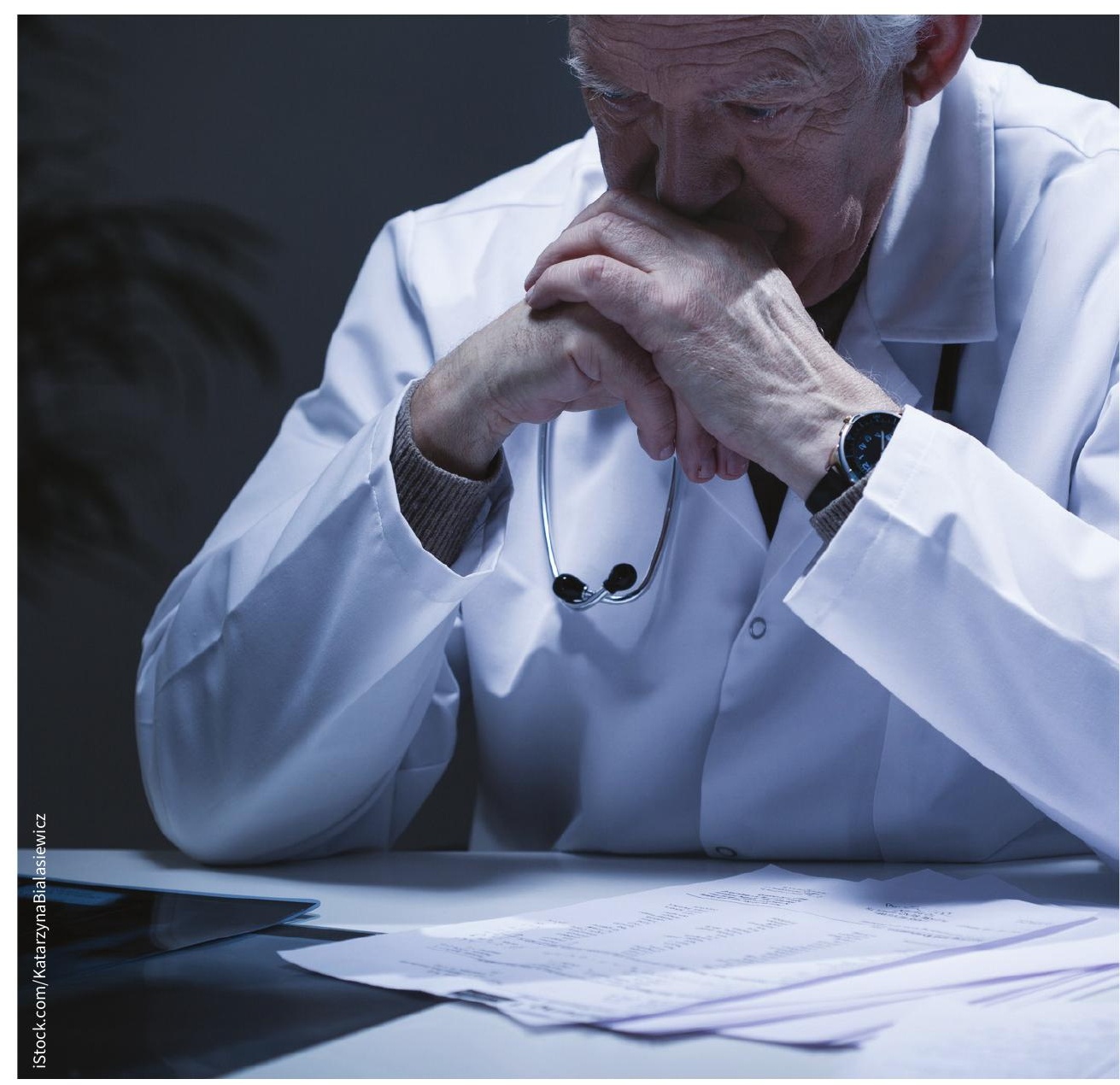

There are options for medical organizations to help physicians have financial security in their old age. 
about $10 \%$ of private plans are defined benefit now, said Hamilton. "It's not a risk an employer can bear."

According to Newton, however, things have changed since the auto industry ran into problems, and it is possible to establish defined benefit plans on a stable basis. If there are not enough assets to support benefits, contributions can be increased or benefits can be reduced. But that raises issues of intergenerational fairness, said Hamilton, because younger doctors would have to pay more for fewer benefits.

A defined benefit plan is also more complicated to set up. The committee would have to select an actuary to set the benefits, and a custodian, such as an insurance company or trust, to hold the assets. It would have to be registered with the Canada Revenue Agency and a pension regulator in at least one province.

A defined contribution plan is much simpler and can be set up with just an insurance company. The committee would select a range of investment options, and the plan would essentially act as a group RRSP, with each contributor receiving benefits based on what they paid in, depend- ing on how the investments performed. The advantage over a personal RRSP is that the tax benefits and contribution limits are greater. The Canadian Bar Association uses a defined contribution plan.

Another option would be to create a group personal pension plan, said JeanPierre Laporte, CEO of Integris Pension Management. Personal pension plans can be set up by any doctor registered as a professional corporation and provide better returns and tax benefits than an RRSP. They can be combined into a group plan, which provides more flexibility for individual doctors to tailor their investments than a group multi-employer plan.

The CMA's \$2.6 billion would not be enough to sustain a pension for all Canadian doctors, if it were legally possible, though perhaps it is enough money to create such a plan and provide oversight, some physicians have noted in online discussions. In any of the legally viable plans, most of the contributions would have to come from doctors themselves, and if 80000 or more doctors contributed to a fund, it wouldn't take long for it to grow.

Although the CMA may not be able to contribute directly to a pension fund, it could subsidize contributions or tweak fees to make a plan more attractive, said Newton and Laporte. Any of these options would be easier and faster than trying to get the government to change tax laws, said Laporte. "There is no need to lobby the government or set up new bureaucracy."

The CMA hired the human resources consulting firm Mercer to explore possible retirement vehicles for physicians. The resulting report focused on working within the existing system "with consideration of potential industry innovations or changes to the legislative environment." It explored the pros and cons of multi-employer benefit plans, streamlined group individual pension plans and capital accumulation plans (such as RRSPs and TFSAs).

"The Mercer report's mission was to identify all possibilities for retirement vehicles for physicians," the CMA said in a statement. "With the report now being public, we're interested in hearing from members and exploring with them if any of these options would be of interest."

Brian Owens, St. Stephen, NB 